\title{
Strategic risk, banks, and Basel III: estimating economic capital requirements
}

\author{
Arun Chockalingam
}

School of Industrial Engineering, Technische Universiteit Eindhoven, Eindhoven, The Netherlands

Shaunak Dabadghao

Technische Universiteit Eindhoven, Eindhoven, The Netherlands

Rene Soetekouw

School of Industrial Engineering, Technische Universiteit Eindhoven, Eindhoven, The Netherlands
Strategic risk, banks and basel III

Received 4 November 2016

Revised 16 February 2017

10 April 2017

13 June 2017

Accepted 1 July 2017

\begin{abstract}
Purpose - Basel III regulations require banks to protect themselves against strategic risk. This paper aims to provide a comprehensive and measurable definition of this risk and proposes a framework to estimate economic capital requirements.

Design/methodology/approach - The paper studies the literature and solicits expert opinion in formulating a comprehensive and measurable definition of strategic risk. The paper postulates that the economic capital for a bank's strategic risk should be estimated using the cost of equity as the profitability threshold, rather than zero and develops a simulation-based framework to estimate economic capital.

Findings - The framework closely matches the actual economic capital outlay for strategic risk from our case study of ABN AMRO. It is shown that a bank's strategic growth plans can fall into one of two scenarios based on risk-return characteristics. In one scenario, the required economic capital outlay will increase, and decrease in the other.

Practical implications - This framework is generalizable and makes use of widely accepted and used practices in banks, making it readily implementable in practice. It does not introduce errors resulting from model selection, parameterizations or complex calculations.

Social implications - Society would be worse off in the absence of banking and lending services. Banks need to take risks to grow and stay competitive. The framework facilitates better strategic risk management, protecting banks from collapse and reducing the need for taxpayer-funded bailouts.

Originality/value - The paper provides a measurable and practitioner-verified definition of strategic risk and proposes a simple framework to estimate economic capital requirements, a crucial topic, given the threats and increased levels of strategic risk facing banks.
\end{abstract}

Keywords Risk management, Basel III, Financial institutions, Economic Capital, Strategic risk

Paper type Research paper

(C) Arun Chockalingam, Shaunak Dabadghao and Rene Soetekouw. Published by Emerald Publishing Limited. This article is published under the Creative Commons Attribution (CC BY 4.0) licence. Anyone may reproduce, distribute, translate and create derivative works of this article (for both commercial and non-commercial purposes), subject to full attribution to the original publication and authors. The full terms of this licence may be seen at http://creativecommons.org/licences/by/4.0/legalcode

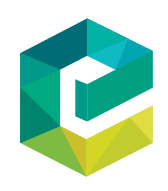

The Journal of Risk Finance Vol. 19 No. 3,2018 pp. $225-246$ pp. 225-246
Emerald Publishing Limited Emerald Publishing Limited
$1526-5943$ DOI 10.1108/JRF-11-2016-0142 
JRF
19,3

226

\section{Introduction}

Banks and financial institutions provide a variety of essential services that are key to the functioning of the global economy. Like other business entities (firms), banks face a multitude of risks. As Stulz (2014) notes, unlike other types of firms, the failure of banks can have systemic effects. Lending to less credit-worthy customers, securitizing and trading these mortgages were part of a flawed strategy by institutions such as the Federal National Mortgage Association, the Federal Home Loan Mortgage Corporation, Lehman Brothers and AIG. These actions and unprecedented levels of risk-taking led to the Global Financial Crisis (GFC) of 2007, the worst global crisis since the Great Depression (Gorton and Metrick, 2012).

The natural argument in the aftermath of the GFC would be the limitation of the risks banks are exposed to, so as to prevent crises such as the GFC from occurring again. Stulz (2014) argues that while limiting the systemic risk a bank creates is important for society, there is no a priori reason that a bank that has less systemic risk is worth more for its shareholders. Consequently, a bank that maximizes its value for its shareholders may have an amount of systemic risk that is excessive from the perspective of society. Indeed, risktaking in itself is not inherently a negative activity. All businesses need to take on some level of risk to grow and remain competitive. Consequently, the emphasis then lies in taking on appropriate levels of risk and managing these risks.

The GFC led to the collapse of several banks worldwide. Some of these banks, deemed "too big to fail" or "systemically-important banks", had to be nationalized. These include the largest commercial banks in Iceland, Northern Rock and the Royal Bank of Scotland in the UK and ABN AMRO in The Netherlands, among others. The bailout was not limited to banks. The US Government had to bailout AIG and General Motors after the events of the GFC. These bailouts had to be funded by taxpayers. The impact of the GFC on taxpayers underscores the importance and necessity of sound and effective risk management principles in banks.

Given the need for risk-taking and the importance of risk management by banks and financial institutions, in the aftermath of the GFC, regulatory authorities have introduced or strengthened regulations that focus on the risk borne by these institutions, and the management of these risks. The Dodd-Frank Act, introduced as a consequence of the GFC, focuses on ending the concept of "too big to fail" and taxpayer-funded bailouts. One aspect of the act focuses on reducing the amount of speculative investments on a firm's balance sheet. The first two Basel Accords were extended by the installment of the third Basel Accords, commonly referred to as Basel III. This third installment was developed as a consequence of the deficiencies observed in the financial regulations during the GFC. Basel III is stated to be a comprehensive set of reform measures to strengthen the regulation, supervision and risk management of the banking sector and focuses on strengthening bank capital requirements.

Risk management in banks, while clearly important, is complicated by the very nature of banks and the types of risks that they face. Banks are highly sensitive to fluctuations in the market (market risk), can suffer defaults on loans (credit risk) and suffer losses due to internal operational issues (operational risk). In addition to these forms of risk (which have been extensively studied in the literature), banks also face risk resulting from changes in strategic decisions and the business environment (e.g. competitors that enter the market or changing customer demand). This form of risk is typically termed as strategic or business risk. A concrete example of this risk type is the impact the entrance of online banks has had on the profitability of existing traditional banks. Credit and market risk pertain to asset losses (for example, losses on loans and on positions in the market), while strategic risk and operational risk are related to the decline of income due to strategic or operational events (for 
example, losses that affect the profit and loss statement due to fraud in the case of operational risk or losses due to a disruptive competitor in the case of strategic risk). Risk management practices in banks therefore require identification and classification of these risks, and the formulation of strategies to mitigate against these identified risks.

McConnell (2012) argues that strategic risk is the greatest risk facing any firm, especially systemically important banks, given the immense uncertainty in the global economy. Indeed, Basel Committee on Banking Supervision (2015) notes that strategic risk has caused banks to fail during the GFC. McConnell (2013) breaks strategic risk into strategic positioning risk and strategic execution risk. Strategic positioning risk refers to the whether the bank is headed in the right direction with its strategy. Strategic execution risk refers to whether the strategy is being executed properly, and if the objectives are still meaningful.

Banks are facing higher levels of strategic risk in current market conditions, with the entrance of companies specializing in combining finance and technology (commonly referred to as Fintechs). Fintechs are competing with banks in areas such as loans, investments and digital payments, areas that have been particularly profitable for and previously dominated by financial institutions and banks (De Nederlandsche Bank, 2016, Mackenzie, 2015). De Nederlandsche Bank (2016) focuses on the impact of Fintechs on banks operating in The Netherlands. Investments in Fintechs has been increasing over the years (Haddad and Hornuf, 2016), highlighting the growth of the Fintech market. Europe in particular is experiencing a continued rise in the number of and investments in Fintechs (CB Insights, 2016). Philippon (2016) attributes the growth of Fintechs to the inefficiency and high cost of financial services offered by banks. In a recent survey (PwC, 2016), 95 per cent of responding banks state that their business is at risk as a result of the growth of Fintechs. These banks state that 24 per cent of their business is at risk. Noonan (2016) reports that the growth of Fintech firms is estimated to spur a cut in almost two million banking jobs.

Fintechs are also starting to offer supply chain finance solutions, another area that has been dominated by banks. These actions by the Fintechs have started to erode the profit margins of banks. Looming deregulations of the banking sector also pose a higher level of strategic risk for banks. In the aftermath of the GFC, regulations on banks and financial institutions required the formulation of new strategies to operate in a tighter market. Now, with geopolitical shifts, regulatory authorities are mulling over the relaxation or repeal of some of the previously enforced regulations. The freedom afforded to banks and financial institutions with the deregulation will again require the formulation of new strategies, thereby increasing the level of both strategic positioning risk and strategic execution risk.

Despite its significance, the coverage of strategic risk in the academic literature has been rather scarce. In fact, while the other forms of risk described above have clear definitions, there is no single, unified definition of strategic risk or business risk. In addition to having clear definitions, the other forms of risk, especially credit risk, also have been treated extensively from a risk management perspective. One possible reason for the scarcity in the coverage of strategic risk could be that it has been considered as a part of operational risk, as in Schroeck (2002). Another contributing factor could be that from a practical perspective, the question of who is responsible for the management of strategic risk in a bank arises (Stulz, 2014).

The above arguments clearly demonstrate the threat posed by the strategic risk faced by banks, and the need for effective risk management policies to mitigate against it. Furthermore, McConnell (2013) examines the collapse of Lehman Brothers during the GFC and notes that risk management policies that ensure that taxpayers need not fund bailouts of institutions if/when strategies fail are needed. Measuring strategic risk, however, is not straightforward, as strategic risk has to be measured by observing deviations from the 
strategy formulated by the board (McConnell, 2012). The author posits that the starting point of the measurement or quantification of strategic risk is the assessment of economic capital.

Economic capital refers to the capital buffer that a bank needs to set aside to protect itself from adverse events and mitigate against risk. The capital requirements prescribed in the Basel III framework refer to the economic capital that banks need to hold. Assessing the amount of economic capital a bank needs to hold for mitigation against strategic risk allows the bank to quantify its risk exposure and formulate risk management policies.

Motivated by the significance of the threat posed by strategic risk in banks, the increased prevalence of strategic risk under current economic conditions, the scarcity of the coverage of strategic risk in the literature, and the increased importance of economic capital in the wake of the Basel III framework, this paper focuses on the quantification of a bank's exposure to strategic risk. Specifically, we make two contributions. To measure strategic risk, we first propose a comprehensive definition, based on the literature, and interviews with some senior executives in Dutch banks. Further, we make use of documentary evidence (in the form of annual reports) from Dutch banks in formulating our comprehensive definition of strategic risk. Our focus on Dutch banks stems from the Netherlands' stature as a small bank-oriented country with a large dependence on banking institutions, and a financial sector dominated by systemically important institutions that operate in diverse domestic and international markets (International Monetary Fund, 2011). Furthermore, as highlighted in De Nederlandsche Bank (2016), CB Insights (2016), Haddad and Hornuf (2016), the Fintech sector has experienced remarkable growth in The Netherlands, competing with Dutch banks and exposing them to strategic competition. The proposed definition facilitates the quantification of strategic risk by incorporating an objective measure. As McConnell (2012) notes, the outcome of a strategy formulated by a board can only be observed three to five years after the strategy has been formulated. Should the strategy be flawed, waiting to observe the outcome of the strategy could prove disastrous. A definition that allows for the continuous quantification of strategic risk is therefore required. The definition that we propose incorporates an objective measure that allows for this continuous assessment. Given that the starting point of measuring strategic risk is the assessment of economic capital, our second contribution is a methodological contribution. We develop a framework that allows for the quantification of strategic risk by estimating the amount of economic capital that a bank needs to hold to mitigate against its strategic risk. Such a framework could prove especially valuable given that the capital requirement regulations in Basel III will soon go into effect. In addition to facilitating the estimation of economic capital requirements, the developed framework can be used to evaluate the impact of selecting risk appetite levels (acceptable levels of risk) and growth strategies.

The paper is structured as follows. We review the literature pertaining to the definition and quantification of Strategic Risk in Section 2. Section 3 describes our methodology, namely, the use of academic literature and interviews with experts to arrive at our measurable definition of strategic risk, followed by the use of the definition to construct the framework to estimate economic capital for strategic risk. We illustrate the application of the developed framework with a case study, based on ABN AMRO (which had an Initial Public Offering in November 2015) in Section 4. We present concluding remarks in Section 5.

\section{Literature review}

As mentioned in the introduction, banks face many kinds of risks usually classified under credit risk, market risk, operational risk and strategic or business risk. We note that the terms strategic risk and business risk are used interchangeably and defined in a similar 
fashion in the literature, statements from banks and regulatory authorities. Credit risk and market risk have been extensively studied in the literature: Duffie and Singleton (2012) and Lando (2009) on evaluating, pricing and quantifying credit risk, and Artzner et al. (1999) on definitions and methods for measurement of market risk. Strategic risk, focusing on losses realized on income, has received much less attention due to difficulties pertaining to its definition and quantification, as pointed out in McConnell (2016). This is probably also due to the fact that there is no generally agreed definition for the term "strategy" itself. In this section, we will review in brief, some academic and regulatory literature on the definition and quantification of strategic risk. We will demonstrate how the definition of strategic risk has evolved over time by examining Schroeck (2002), Slywotzky and Drzik (2005), Doff (2008), McConnell (2012) and McConnell (2013), along with several regulatory articles as well as formal definitions from the banking institutions themselves. In Tables AI and AII, we show the current definitions that the banks operating in The Netherlands adopt for strategic or business risk.

We begin our review with Schroeck (2002), in which the author classifies business risk and event risk as a part of operational risk. The author defines operational risk as the risk of experiencing unexpected (financial) losses due to failures in people, processes or systems and their (internal) controls or from external (non-market or non-credit-risk) events and a bank's business strategy/business environment. This definition differs from the definition of operational risk, as it is currently used in banks. Banks equate operational risk to event risk, which Schroeck (2002) defines as losses due to process failures, systems failures, fraud, legal claims or external disruptions that are caused by a rare event. This is, in essence, the definition of operational risk in Basel Committee on Banking Supervision (2006, 2009), European Parliament (2013) and Sweeting (2011). The author also defines business risk as the loss of unforeseeable changes in either revenues or fixed costs that are caused by changes in the banks competitive environment. These changes in the competitive environment are, for example, price wars, new market entrants or changes in regulation. The European Parliament, however, does not include external events resulting from strategic risk in operational risk (European Parliament, 2013), therefore comprising only a part of Schroeck's definition of operational risk. Basel Committee on Banking Supervision (2011) even explicitly excludes strategic risk from operational risk, defining operational risk as the risk of loss resulting from inadequate or failed internal processes, people and systems or from external events. This definition includes legal risk, but excludes strategic and reputational risk. We observe that over time, strategic risk began to be defined on it is own, differentiating it from operational risk.

This differentiation is clearly observed in the definition of strategic risk in Slywotzky and Drzik (2005). In brief, the authors point out that strategic risk is the risk arising from the array of external events and trends that can devastate a company's growth and value. The authors provide a comprehensive set of external events as well as a broad risk governance framework, breaking down strategic risk into workable determinants. The external trends or events identified are industry margin squeeze, technology shift, brand erosion, one-of-akind competitor, customer priority shift, new-project failure and market stagnation.

Doff (2008) provides a definition for the term business risk and discusses whether business risk can be calculated within an economic capital framework. The author focuses on addressing business risk in a banking environment and examines situations in which economic capital is a suitable solution to absorb losses caused by strategic/business risk. Business risk is defined as the risk of financial loss due to changes in the competitive environment, or the extent to which the organization could adapt to these changes in a timely manner. The author uses two determinants, "adaption to changes" and "competitive 
JRF
19,3

230

environment" from the definition to classify different combinations of adaption and environment into: low, medium or high business risk. Table I provides the result of this classification.

Furthermore, Doff (2008) distinguishes between two components of changes in the competitive environment. First, changes may occur abruptly or gradually. Second, changes may be permanent or temporary. The author argues that only the combination "abrupt temporary changes" and "abrupt permanent changes" are worthwhile to mitigate with an economic capital buffer. There is no need to mitigate the other two combinations with an economic capital buffer. The logic behind this claim is intuitively simple. When changes occur gradually, it is better to adapt the organization. Consequently, economic capital can be used to absorb losses during:

- a short crisis in case of an abrupt temporary change;

- the time lag between an event and successful management interaction; and

- the initial investment of a change in the internal structure of the organization.

In McConnell (2012), the author argues that strategic risk is the greatest risk facing any firm. Further, the author outlines a list of questions that provide a high level perspective of the strategic risk a firm faces and distinguishes between strategic positioning and strategic execution risks. In both McConnell (2012) and McConnell (2013), the author points out that banks and financial institutions illustrated a lack of proper strategic risk management and that this discipline lacks maturity. McConnell (2013) provides several examples that demonstrate how institutions with aggressive growth strategies failed to manage the inherent risks, highlighting the need for proper risk management policies, and the role of regulatory authorities in ensuring that these policies are in place. Following the events precipitating the GFC, regulatory authorities started to focus on the definition and mitigation of strategic risk.

Basel Committee on Banking Supervision (2009) defines business risk as the risk that volumes may decline or margins may shrink, with no opportunity to offset the revenue declines with a reduction in costs. For example, business risk measures the risk that a business may lose value because its customers sharply curtail their activities during a market down-turn or because a new entrant takes market share away from the bank. Moreover, this risk increasingly extends beyond balance-sheet items to fee-generating services, such as origination, cash management, asset management, securities underwriting and client advisory services. This definition is used in the economic capital framework proposed in Basel Committee on Banking Supervision (2009) and states that strategic risk has an effect on the profit and loss statement as it addresses declines in revenues and extends beyond balance sheet items. Therefore, strategic risk needs a forward-looking approach and depends on future cash flows.

Following the GFC, and the emphasis placed on the mitigation of strategic risk by regulatory authorities, banks and financial institutions also began focusing on the mitigation of strategic risk, with banks including definitions of strategic risk in their annual

Table I.

Components of business risk, Doff (2008)

\begin{tabular}{lll}
\hline & $\begin{array}{l}\text { Quick-to-adapt } \\
\text { Internal organization }\end{array}$ & $\begin{array}{l}\text { Slow-to-adapt Internal } \\
\text { organization }\end{array}$ \\
\hline $\begin{array}{l}\text { Dynamic } \\
\text { Environment stable environment }\end{array}$ & $\begin{array}{l}\text { Medium business risk } \\
\text { Low business risk }\end{array}$ & $\begin{array}{l}\text { High business risk } \\
\text { Medium business risk }\end{array}$ \\
\hline
\end{tabular}


reports. Thus, in addition to the literature, the annual reports of banks that operate in The Netherlands were examined. These banks include ABN AMRO, ING, Binckbank, Deutsche Bank, Rabobank, Van Lanschot, SNS, NIBC and RBS. In every annual report, the words "Business Risk" and "Strategic Risk" were searched for and the corresponding definition studied.

Five of these banks use the term business risk. Deutsche Bank states The most material aspect of Business Risk is "Strategic Risk", which represents the risk of suffering unexpected operating losses due to decreases in operating revenues which cannot be

Strategic risk, banks and basel III compensated by cost reductions within the respective time horizon" (Deutsche Bank, 2015, p. 267). This statement by Deutsche Bank corresponds with the definition of ING, which also explicitly mentions the inclusion of strategic risk in the business risk definition. Abn Amro does not mention strategic risk as part of business risk. However, the statement: "[. . .] the risk that earnings will fall below the fixed cost base, due to changes in margins and volumes", more or less equals the strategic risk definition of Deutsche Bank and ING. RBS uses business risk more as a collection of different external risk types and disclose strategic risk separately.

The other banks use the term strategic risk. Van Lanschot sometimes uses the term business risk to indicate strategic risk. Both terms have the same meaning in the annual report of Van Lanschot; taking into account that Van Lanschot did not give a separate explanation of the term business risk as it did for strategic risk. NIBC introduces a new term, "Strategic Business Risk". Rabobank mentions it in their annual report next to operational risk, but does not give a definition.

It should be noted that the literature often refers to loss as strategic risk; however, some banks use definitions such as: "decline in earnings", "lower income" and "deviation from expectations". This suggests that considering only losses as strategic risk might be an underestimation, an idea which we consider very important. Also we observe that these definitions are quite qualitative. "How much of a decline in earnings?", "how large a deviation from expectations?" - these questions are important to be able to quantify strategic risk. To answer these questions, we define what we call the profitability limit, which we will cover in the next section.

\subsection{On quantifying strategic risk and economic capital}

Economic capital has many definitions in literature. Sweeting (2011) states that economic capital refers to a surplus of assets or cash flows to deal with an unforeseeable decrease in assets or rise in liabilities over a predefined period within specific risk limits. The Bank of International Settlements (BIS) Basel Committee on Banking Supervision (2009) defines economic capital as procedures or routines of banks to evaluate risk and cover the financial impact due to banks' risky activities. The definition given by the BIS differs from the definition in Sweeting (2011) in a way that economic capital can be seen as a banks measurement of overall risk or risk across business units and not as a capital buffer. Economic capital in the context of a banks' risk management is not a mandatory capital buffer as is the regulatory capital under Pillar 1 of the Basel framework. In practice, there is not a single methodology for banks to assess the economic capital. Therefore, banks use different models and processes in their internal risk assessment (Aas and Puccetti, 2014). The concept, however, is the same across banks. Not all banks allocate or explicitly state the amount allocated to economic capital for business/strategic risk. Of the annual reports examined, three of the five banks that referred to business risk allocate economical capital to mitigate against its effect. SNS and Rabobank do not allocate economic capital for strategic risk, whereas Van Lanschot does. 
On the question of calculating economic capital for strategic risk, the difficulty we notice is in the fact that the definitions are usually qualitative in nature, and not always measurable. The few models that we find in the literature vary drastically in the assumptions they make. At the moment, there are no regulations or guidelines from regulatory entities that address the quantification of strategic risk. Although the Basel Committee on Banking Supervision (2009) argues that strategic risk should be part of the economic capital assessment, it does not provide any guidelines to quantify it. Doff (2008) reports three commonly used methods to calculate the economic capital for strategic risk - analogue company approach/peer group analysis, statistical analysis and scenario analysis - based on the author's own experience with banks. Schroeck (2002) proposes two methods to calculate the economic capital for business risk - a historical accountingbased approach and Monte Carlo simulation. The first one uses historical cost and revenue time series in which all trading and credit related cost and revenues are subtracted. These figures can be used to calculate the expected revenue and its volatility, after which the economic capital for business risk can be calculated. The second approach, Monte Carlo simulation, also depends on historical data and can be done by linking the drivers to a suitable macro-economic model. A more detailed approach is seen in B«ocker (2008), where a discounted cash flow model in continuous time using Brownian motion is used to calculate the capital at risk. Chaffai and Dietsch (2015) define business risk as changes in profit due to a bank's activities. They use a directional distance function to calculate the difference between the current profit and an efficient frontier. The difference is considered as profit inefficiency, which Chaffai and Dietsch see as unexpected loss. There exist few methods in the academic literature for the estimation of economic capital for business risk. As Doff (2008) notes, banks use proprietary methods to estimate this figure. The Monte-Carlo simulation-based method proposed in Schroeck (2002), while similar to our proposed framework, relies on the selection of a suitable macro-economic model. Current methods proposed in the academic literature are sophisticated, but are not easy to implement. The method proposed in Chaffai and Dietsch (2015) is certainly sophisticated but requires computation of the efficient frontier and the directional distance function. The methods used to compute these could introduce errors into the estimation, thereby skewing the economic capital estimation.

Consequently, there exists a requirement for a method or framework to estimate economic capital for strategic risk/business risk that is simple to implement and will not introduce errors as a result of model selection, parameterizations or complex calculations.

\section{Defining and quantifying strategic risk}

In this section, we propose a definition for strategic risk and then provide a method to quantify it. We do so by first identifying (or setting) a profitability limit. The deviation of returns from this limit provides us with a measure of strategic risk.

In this section, we describe our methodology in estimating economic capital for strategic risk. The first step involves formulating a measurable definition of strategic risk. We arrive at our proposed definition, presented in Section 3.1 by analyzing the definitions of strategic risk in the academic and regulatory literature as well as the definitions provided in the annual reports of banks. The interviews with industry experts validate our proposed definition. With the newly formulated and validated definition, we then construct a framework that facilitates the quantification of strategic risk by estimating the economic capital requirements for mitigation against strategic risk. 


\subsection{Defining strategic risk and profitability limit}

Decreases in net income caused by strategic events form the core element of strategic risk. It can be argued that the main challenge is to stay profitable in a changing business environment by engaging in a sustainable business strategy. However, "being profitable" is a broad statement and deserves more attention, as it can be interpreted in many ways. In the trivial case, when an activity registers a loss, the situation can be clearly deemed as nonprofitable. Further, profitability can refer to a degree of "acceptable" returns. For instance, an activity that has a revenue of $\$ 100 \mathrm{~m}$ in the previous year will be deemed profitable when the shareholders required a revenue of at least $\$ 50 \mathrm{~m}$. If revenues fall to $\$ 20 \mathrm{~m}$ in the current year, the activity will be deemed unprofitable according to shareholder standards, even if it has a positive return. This is important information for shareholders as well as rating agencies. Thus, any definition for strategic risk must also include information for measurement of "deviation from acceptable" - what we call the "profitability limit" that determines the acceptability of a cash flow.

Basel Committee on Banking Supervision (2015) argues that the lack of profitability is considered a major symptom in the assessment of weak banks. To identify and deal with weak banks, they provide guidelines to the supervisory community in which they provide symptoms and causes of bank problems. They argue that supervisors should assess profitability on a forward-looking basis and should include early warnings in the assessment of the business model. These guidelines clearly imply that the limit of profitability is a value above zero. Therefore, setting an early warning limit on zero will lead to losses before any corrective action can be taken. Another point of view that leads to the same conclusion is that corrective action in banks is often undertaken when they either under-perform compared to peers or are out of budget. Such action can be prompted even when the bank generates a profit - thus leading to the conclusion that the profitability limit is greater than zero.

McKinsey (2015) assesses the profitability of banks by comparing the return on equity (ROE), defined as net income after taxes over the shareholders equity, with the cost of equity $(\mathrm{COE})$, defined as the shareholders' minimum required ROE. The firm is less attractive to shareholders when the ROE is less than the COE. If ROE falls below COE, it will lead to a situation in which shareholders are not willing to invest because the required ROE is not reached. The COE is therefore a useful tool to determine the profitability limit. The capital asset pricing model (CAPM) can be used to easily estimate the COE of a firm. The COE equals the amount of equity of the firm times the required rate of return $r$ which is calculated as:

$$
r=r_{f}+\beta\left(r_{m}-r_{f}\right)
$$

where $\beta$ can be calculated as $\beta=\frac{\operatorname{COV}(r, r m)}{\operatorname{Var}(r m)}, r_{m}$ is the market's rate of return and $r_{f}$ is the risk free rate of return. The $\mathrm{COE}$ can be assumed to be constant or allowed to vary over time with $r$ and the value of equity. This view on the profitability limit was also reflected in our discussions with industry experts. We interviewed over a dozen people early in 2016 - a list that includes CFO's, Managing Directors and Risk Managers from banks operating in The Netherlands and financial consultants. We received a lot of feedback on our definition as well as their own views on strategic risk and regulatory capital requirements. We note that the feedback on our definition of strategic risk was broadly similar irrespective of bank size. One CFO notes that "fewer people need loans, therefore our interest income will decline". This brings focus on fee-generating activities that have lower margins than loans, which the CFO categorizes as strategic risk. During these interviews, we also collected their opinions 
on factors that constitute strategic risk. We began with the list from Slywotzky and Drzik (2005), and built on it with the feedback from the industry experts. They notice a changing business environment due to the rise of Fintechs and non-banks that do not have to comply with regulatory requirements, a view also shared by the Dutch regulatory authority (De Nederlandsche Bank, 2016). These new competitors understand customer needs better and have more flexible cost structures. Low interest rates lead to a decline in income; upcoming technologies like Blockchains indicate a technology shift; demographic threats such as decline in population leading to a smaller market for loans and market stagnation; and rise of Fintechs leading to competition; all point toward a decrease in future revenue streams, thus outlining the strategic risks faced by banks today. They also elaborate on the inclusion of the net income of all income generating activities that are not attributable to market risk, credit risk or operational risk. For instance, impairment on loans can affect the net income, but these should not be included in any analysis for strategic risk. Filtering these kinds of costs out of the data is one major issue given the complex operations of banks, leading also to a difficulty in quantifying strategic risk.

Building on existing literature by Slywotzky and Drzik (2005) and Doff (2008), annual statements from banks and our discussions with industry experts, we propose the following definition for strategic risk:

The risk of decline in net income, below a set limit, due to unforeseeable changes in either revenues or fixed costs that are caused by external trends in the banks' competitive environment or the extent to which the organization could timely adapt to these trends. These external trends in the competitive environment can be: (one-of-a-kind) competitors, technology shift, customer priority shift, new-project failure, market stagnation, changes in regulation, industry margin squeeze and brand erosion. This risk increasingly extends beyond balancesheet items to income generating activities, which are not attributable to position taking, credit losses or operational events. Income generating activities are: selling loans, origination, cash management, asset management, securities underwriting, payment services and client advisory services.

\subsection{Estimation of economic capital for strategic risk}

The generally accepted definition of economic capital is the capital made available to absorb the unexpected losses that a bank may face. Economic capital is viewed as a tool to quantify a firm's total risk exposure that can help to ensure that business activities stay within the acceptable risk limits. It is also helpful for supervisors to assess a bank's risk level and to benchmark among the industry having one measure of risk. It should be noted that risk models to calculate economic capital among banks will differ and therefore will lead to different outputs, which makes it difficult to compare among banks. During our interviews with industry practitioners, we noticed that the methods used in estimating the economic capital for strategic risk are different. Many institutions that report economic capital for strategic risk estimate the values using peer reviews, statistical methods and scenario-based analysis, also mentioned in Doff (2008). We noticed that certain institutions in The Netherlands regard economic capital for strategic risk as the cost of liquidation. We also received feedback on whether a capital buffer is necessary for strategic risk. Usually, no buffer is maintained when firms execute strategic plans. Some experts felt that holding such capital may even have a detrimental effect on the firm.

We propose a simple simulation-based method to estimate the economic capital. Based on the Basel Committee on Banking Supervision (2009), we use the well-known and easy-tointerpret risk measures of value-at-risk (VaR) and expected shortfall (ES). Economic capital 
for strategic risk can be estimated from the income statement of a firm, as the strategy of the firm will affect its profitability in a changing business environment. To estimate the future net income, we use a stochastic process following the model of Böocker (2008). Brownian motions allow for inclusion of a trend and volatility, are heavily discussed in literature and easy to interpret - making them highly suitable for this purpose. The net income can be modeled as:

$$
X_{t}=X_{0}+\mu t+\sigma B_{t}
$$

where $B_{t}$ represents the Brownian motion, and $\mu$ and $\sigma$ represent the drift and volatility of the net income. The drift assumes the role of the indicator of the firm's strategic growth.

Figure 1 gives an idea on how this is calculated. A usual confidence limit is set at 99.95 per cent, but this may vary among the banks. As seen in the figure, the economic capital will either be the unexpected loss if the reserves for loss are already allocated, or it will be the $\mathrm{VaR}$ when the reserves are not allocated.

Armed with the estimation technique for the net income and the profitability limit, we can now estimate the economic capital for strategic risk. A firm's strategic initiative usually has a horizon of three to five years, and we can run the simulation for a time frame that suits our needs. Each simulation run of the Brownian motion represents a different market scenario and the economic capital outlay is different for each.

This is easily calculated as:

$$
\mathrm{EC}_{i}=\frac{\Sigma}{t} \max \left(\text { limit }-x_{t, i}, 0\right)
$$

where "limit" represents the COE.

After sufficient simulation runs, we can determine the distribution function of the economic capital, $f(\mathrm{EC})$ and its cumulative distribution function, $F(\mathrm{EC})$. This is used to determine the VaR:

$$
\operatorname{VaR}_{\alpha}(\mathrm{EC})=\sup \{x \mid F(\mathrm{EC}<x) \leq \alpha\}
$$

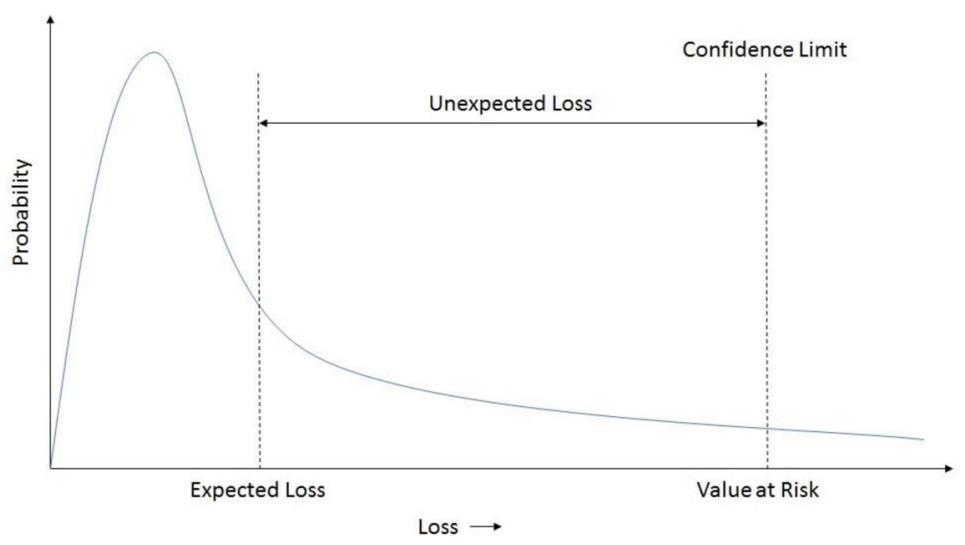

Figure 1. Loss distribution 
The value chosen for $\alpha$ is usually very close to 1 . The ES can now be easily calculated as well:

$$
\mathrm{ES}_{\alpha}(\mathrm{EC})=\mathrm{E}\left[\mathrm{EC} \mid \mathrm{EC}>\operatorname{VaR}_{\alpha}(\mathrm{EC})\right]
$$

\section{$236 \quad 4$. Case study}

In this section, we apply the framework described in the previous sections to estimate the economic capital for strategic risk for a multinational bank. Our case study makes use of documentary evidence from ABN AMRO, a Dutch bank. Our motivation for focusing on the Dutch banking sector was discussed in Section 1. Our selection of ABN AMRO for the case study stems from the fact that ABN AMRO is a globally systemically important banking institution. Furthermore, ABN AMRO was acquired by RBS in 2007 and after the GFC of 2008, RBS had to be bailed out by the British Government, and ABN AMRO was nationalized by the Dutch Government. Furthermore, ABN AMRO release information about their economic capital for strategic risk in their annual statements which we use to measure the performance of our framework. This makes a strong case for using ABN AMRO as a case study to show how our framework can be applied to estimate economic capital for strategic risk. We remark that the framework can be applied to estimate economic capital requirements for other banks provided that the relevant parameters are known or can be estimated (for example with quarterly or annual statements).

\subsection{Data}

Quarterly reports of ABN AMRO from 2012 to 2015 were obtained from their website(ABN AMRO, 2015). Underlying profit, equity amount, return on equity and the loan impairments are noted in Table II. Using net income directly can have some downsides, as it represents an accounting value. To reflect the effect of the firm's strategy, we should first adjust the net income figure to ignore any abnormal costs or revenues. For example, the profitability of a firm is affected when it pays fines or legal claims, but these have nothing to do with strategic risk, as defined in the previous section. Two major items that the net income

Table II.

\section{ABN AMRO}

quarterly data, in e million

\begin{tabular}{llccccc}
\hline Quarter & & Equity & Net income & ROE $(\%)$ & Impairment & Net Income + Impairment \\
\hline \multirow{6}{*}{2015} & Q4 & 16,369 & 272 & 7 & 124 & 396 \\
& Q3 & 16,033 & 509 & 13 & 94 & 603 \\
& Q2 & 15,671 & 600 & 15 & 34 & 634 \\
& Q1 & 15,364 & 543 & 14 & 252 & 795 \\
& Q4 & 14,682 & 400 & 11 & 181 & 581 \\
& Q3 & 14,200 & 450 & 13 & 287 & 737 \\
& Q2 & 13,964 & 322 & 9 & 342 & 739 \\
2013 & Q1 & 13,845 & 378 & 11 & 361 & 508 \\
& Q4 & 13,745 & -47 & -1 & 555 & 636 \\
& Q3 & 13,698 & 289 & 8 & 347 & 526 \\
& Q2 & 13,725 & 220 & 6 & 506 & 549 \\
2012 & Q1 & 13,186 & 290 & 9 & 259 & 644 \\
& Q4 & 13,126 & 5 & 0 & 544 & 676 \\
& Q3 & 14,031 & 312 & 9 & 332 & 674 \\
& Q2 & 13,802 & 308 & 9 & 368 &
\end{tabular}


should be adjusted for are the impairment charges and the restructuring costs. In the case of $\mathrm{ABN}$, we notice that the net income plus the impairments is less volatile and has a slight negative trend, whereas the net profit itself is more volatile but has a positive trend. This is mainly due to the fact that the impairments have decreased over the three-year period. This might be actually attributed to better internal processes or a better economic condition that resulted in fewer defaults. Another reason why we should correct the net income for loan impairments is that they are captured already in the regulatory capital for credit risk and by including them for strategic risk analysis would be double counting. Restructuring costs for ABN AMRO are included under "Personal Expenses" and not reported separately. We noticed that the personnel expenses have not changed much over the period under consideration; therefore, we decided not to include them in our analysis. We want to note here that adjustment of income will be different for different banks. For example, the recent penalty imposed by the US Justice Department on Deutsche Bank AG can be seen as a strategic risk, as it affects brand value and its income will need to be adjusted to estimate their economic capital requirements.

We model the net income plus impairment as a Brownian motion and use maximum likelihood estimation to determine its drift and volatility. A Shapiro-Wilks test concluded that the underlying distribution can be accepted as a normal distribution. The second important thing for estimation is the cost of equity for the profitability limit which is obtained using the CAPM formula. ABN AMRO had its IPO in November 2015, which limits us on calculating the $\beta$ using its share prices - because the start of our analysis is 2012. We try to estimate the cost of equity using different values of $\beta$ that correspond to comparable banks. We assume that the risk free rate $r_{f}$ to be 0.67 per cent. The expected market return is set to be 6.67 per cent based on a market report by KPMG (2016) that recommends to use 6 per cent as the market risk premium in The Netherlands. For the analysis, we assume that the $\beta$ of ABN AMRO is 1.15 which yields the COE ( $r$ equity) to be $310 \mathrm{~m}$. The chosen beta is taken from ING Bank, which has a similar profile as that of ABN AMRO.

\subsection{Simulation results}

As discussed in the previous section, the objective of the simulation is to determine the distribution of the economic capital for strategic risk $f(\mathrm{EC})$, using equation (3). We use 0.9995 as the value of $\alpha$. After a million runs, a histogram of the economic capital for strategic risk was generated (Figure 2). The 99.95 per cent upper limit of this distribution is the VaR indicated with the red line.

The VaR for a three-year horizon equals e2.718bn, which equals e0.906bn per year. In 2014, ABN AMRO reported e1.143bn as economic capital for strategic risk, a slightly higher figure than our simulation results. In this simulation, the cost of equity is assumed to be a constant value. Although a constant threshold might be a good assumption, given the short time range of the simulation, it is likely that the amount of equity will change over time. The equity amount of banking firms changes with time as well as with legislative requirements. Furthermore, many banks have internal goals to increase the equity amount to have a more sustainable capital base. To test the effect of a changing COE over time, the simulation will be adapted and allow the profitability limit to increase over time. Before the simulation can be adapted, we first test whether the hypotheses of an increasing equity amount holds for $\mathrm{ABN}$ AMRO. To test this, a simple linear regression represented by equation (6) is applied to the equity of $\mathrm{ABN}$ during the period of study. 
JRF
19,3

238

Figure 2.

Density of economic capital

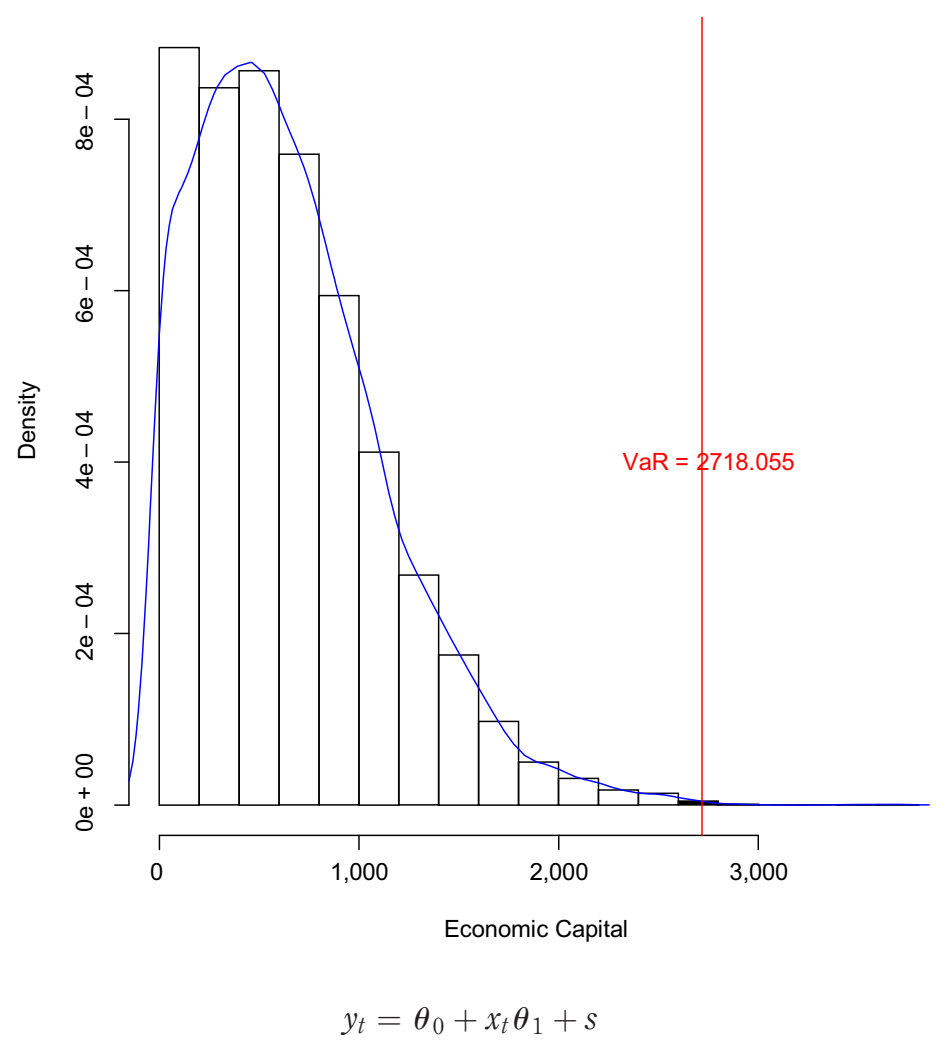

As Table III shows, the equity can be represented as a linear trend. This can easily be incorporated in the simulation as:

$$
\operatorname{limit}_{t}=\operatorname{limit}_{0}+\operatorname{tr} \theta_{1}
$$

This yields a VaR of e3.042m as shown in the Figure 3, or about e1.014m per year. The density of the economic capital is different from when the limit was assumed to be constant, a logical result as a higher limit will result in a larger economic capital.

\subsection{Effects of changes in strategic plan}

The strategic policy of a firm is bound to change its performance in the future. To estimate how a change in the policy can affect its requirement of economic capital for strategic risk, we do sensitivity tests on the ABN AMRO data. We varied the drift in the range of 30 to 30

Table III.

Regression output for ABN AMRO's equity

\begin{tabular}{lclc}
\hline & Coefficient & \multicolumn{1}{c}{$P$-value } & Adj. $R^{2}$ \\
\hline Intercept $\theta_{0}$ & 12697.25 & $1.00483 \mathrm{E}-16$ & \\
COE $\theta_{1}$ & 187.7721 & $1.1389 \mathrm{E}-05$ & \\
Model statistic & & & 0.741 \\
\hline
\end{tabular}




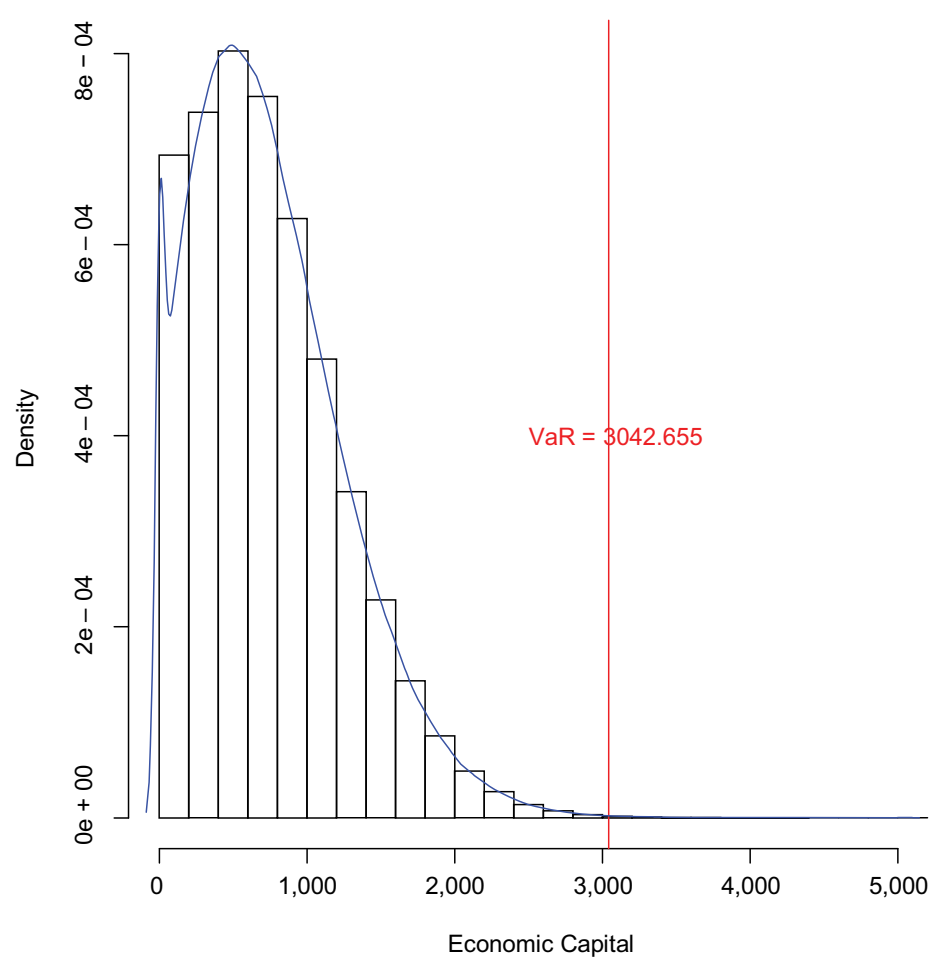

Strategic risk, banks and basel III

239

Figure 3.

Density of economic capital with in- creasing $\mathrm{COE}$

and the volatility from 0 to 170 . Each combination was simulated and economic capital calculated, as shown in Figure 4. We find that the VaR is inversely proportional to the drift but directly proportional to the volatility.

Despite this obvious result, we can draw important insights on how changes in the income growth indicators might affect the VaR in the future. From the figure below, first let us see at what values of the drift and volatility where the VaR is the same as calculated previously at e3.042bn. We can determine the relationship between the income growth, income volatility and the economic capital outlay for strategic risk.

If it is possible to identify the parameters of a new strategy, an estimate can be made on how it can contribute to growth and how the economic capital outlay needs to change. In our example of ABN AMRO, we notice that the combinations of the income growth and volatility that yield the same economic capital outlay have a linear relationship (Figure 5 and Table AI). Suppose that the firm wants to undergo a new strategic plan or execute a project within the current plan which could potentially change the income growth and volatility. Consider two scenarios -1 and 2 - as shown in the Figure 6 . Any new project or shift in strategy would fall under one of these two scenarios - where the income growth and volatility increase. In Scenario 1, an increase in income growth also brings in an increase in income volatility that is much higher than the linear trend we identified. Scenario 2 represents income growth with an increase in volatility that is lower than what the linear trend identifies.

We will first discuss the two extreme cases shown as red lines in Figures 5 and 6 one where the income grows, but the volatility does not, and the other where the income 
JRF

19,3

240

Figure 4.

Sensitivity of the value at risk
Figure 5.

Relationship between growth and volatility yielding the same economic capital
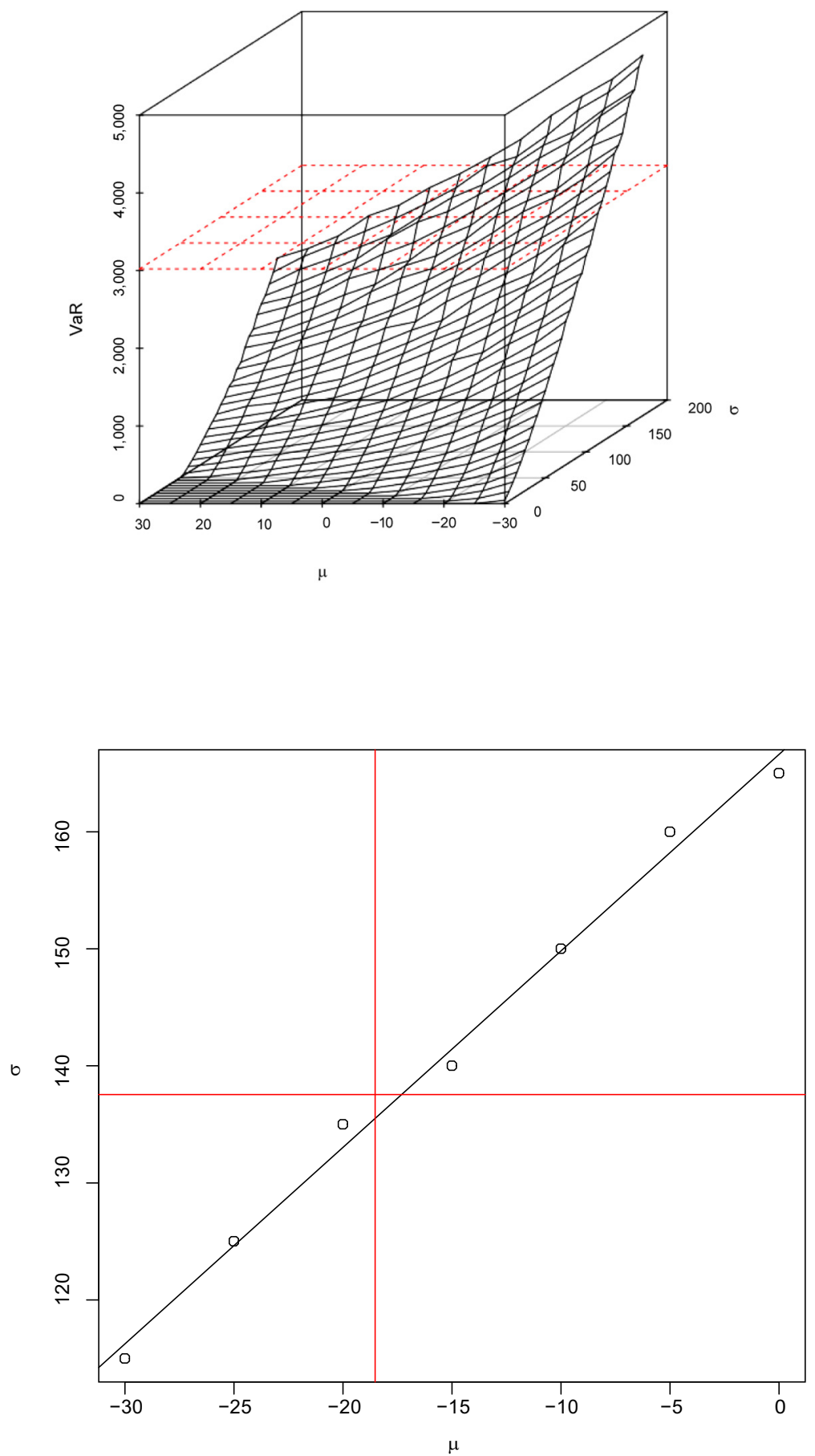


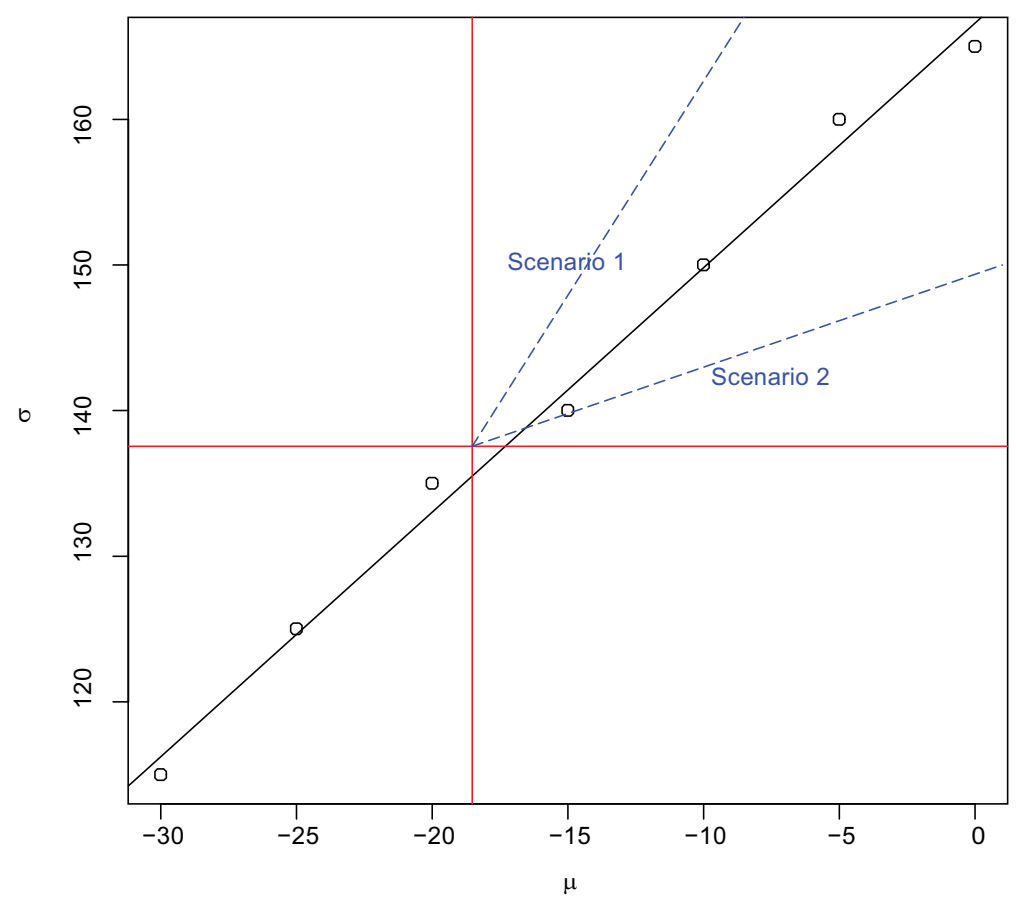

Note: The red lines represent extreme cases
Strategic risk, banks and basel III

241

Figure 6. Strategic Scenarios 1 and 2

volatility increases, but the growth does not. When only the income growth, or the drift parameter increases the VaR decreases. This is an ideal situation for any firm - that a new project or strategy yields guaranteed growth. We also see that the decline in the economic capital outlay decreases asymptotically to zero as the drift parameter increases, as the probability that the income falls under the profitability limit decreases. Clearly, any change that increases income is welcome. However, if the firms' objective is to decrease its VaR, then we can use this scenario to show that not every new project or strategy is worthwhile. The other extreme case is when the income volatility increases, while the income growth is constant. This leads to an increase in the economic capital and is clearly detrimental for the firm.

Figures 7 and 8 provide some interesting relationships between how a firms' new strategy can affect its economic capital for strategic risk. Scenario 1 shows when the income growth leads to higher income volatility, the economic capital increases, whereas we see in Scenario 2 that an income growth with a smaller increase in volatility leads to decrease in the economic capital. This means that the firm should choose projects and strategies that correspond to Scenario 2. In other words, these projects or strategies will lead to higher incomes as well as a higher volatility, but they are more sustainable because the decrease the VaR. A firm should therefore try to implement new projects and strategies that yield an income growth and volatility falling between the observed linear trend from Figure 5 and the extreme case where the volatility does not change. 


\section{JRF \\ 19,3}

242

Figure 7.

Scenario 1

Figure 8.

Scenario 2
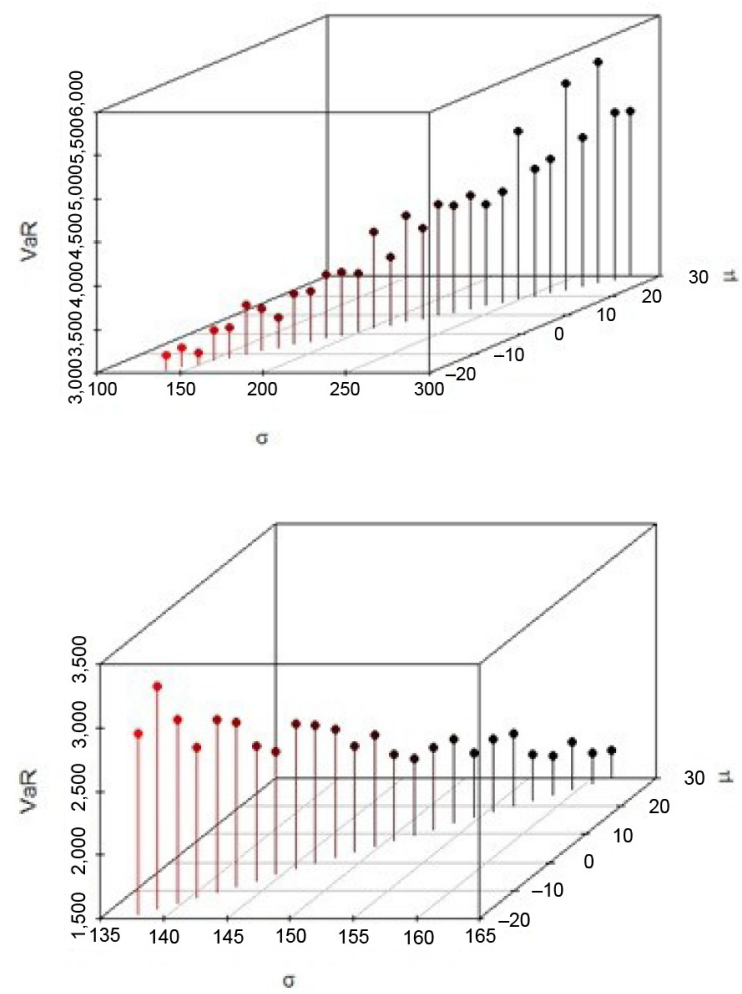

\section{Conclusion}

Like all business entities, banks and financial institutions need to take risks. What distinguishes risk-taking in banks from risk-taking in other types of firms is the fact that the failure of a bank, as a consequence of these risks, can have a systemic effect on the global economy, as demonstrated by the GFC of 2007. A bank faces many types of risks, including market risk, credit risk and operational risk. Strategic or business risk, the risk associated with the formulation and execution of a bank's strategy, is arguably the greatest risk facing banks, given the immense uncertainty in the global economy. Strategic risk also pertains to disruptions in the environment in which the banks operate in. Strategic risk is highly prevalent in current market conditions, with the entrance of online banks and Fintechs, and looming deregulations. Yet, despite its significance in the risk framework, strategic risk has received scarce coverage in the literature. To the best of our knowledge, there exists no measurable definition of strategic risk in the literature.

The strategic risk faced by banks has gained prominence in the aftermath of the financial crisis, with the Basel III Accords identifying strategic risk as a potentially significant risk and requiring that banks hold capital buffers, or economic capital to mitigate against strategic risk. The assessment of the economic capital required to mitigate against strategic risk can also be considered a starting point in quantifying strategic risk.

Motivated by the importance and prevalence of the strategic risk faced by banks, the importance and complexity of managing strategic risk, this paper focuses on quantifying 
strategic risk. As a consequence of the lack of a clear, concise and measurable definition of strategic risk, we first analyze the academic and regulatory literature for definitions of strategic risk. We also analyze annual reports of banks for their definition of strategic risk. Following this analysis, we develop a comprehensive definition of the phrase strategic risk and conduct interviews with several senior bank executives, validating our proposed definition. We then develop a framework that uses the bank's cost of equity as a profitability threshold to estimate the amount of economic capital needed to mitigate against strategic risk. The framework simulates the bank's net income and uses the VaR framework to assess economic capital requirements. In addition to assessing economic capital requirements, the framework also allows a bank to evaluate the impact of selecting a risk appetite, and formulating a growth strategy on its economic capital requirements. The framework presented in the paper is highly generalizable, as it only makes use of parameters estimated from bank data. The framework can be used internally by banks, by regulatory authorities using data provided to them by banks or publicly available data (as we have done in the case study), and by academics.

As mentioned before, strategic risk can be broken down into strategic positioning risk, and strategic execution risk. The developed framework allows a bank to quantify strategic risk as a whole. The framework also allows a bank to evaluate the impact of a change in strategy on economic capital requirements. This is equivalent to quantifying the impact of strategic positioning risk on economic capital requirements. The structure of the framework currently does not allow for quantifying the impact of strategic execution risk on economic capital requirements. Thus, a natural direction for future research would be an extension to the framework to explicitly evaluate the impact of strategic execution risk on economic capital requirements.

In our study, we use interviews with industry experts to help in the formulation of the definition of strategic risk. The views expressed by the industry experts are their personal opinions and therefore pose a limitation to our study. The developed framework makes use the of the $\mathrm{VaR}$ concept to estimate economic capital requirements. Naturally, by making use of this concept, our proposed framework inherits the shortcomings of the VaR concept. Nonetheless, the VaR concept is widely accepted, both academically and practically, and used for risk management purposes in banks. Thus, adopting this concept in our framework facilitates the adoption of the framework by banks and financial institutions.

\section{References}

Aas, K. and Puccetti, G. (2014), "Bounds on total economic capital: the DNB case study", Extremes, Vol. 17 No. 4, pp. 693-715.

ABN AMRO (2015), “Annual statements", available at: www.abnamro.com/en/investor-relations/ financial-disclosures/index.html (accessed 8 September 2016).

Artzner, P., Delbaen, F., Eber, J.-M. and Heath, D. (1999), “Coherent measures of risk”, Mathematical Finance, Vol. 9 No. 3, pp. 203-228.

Böocker, K. (2008), "Modelling and measuring business risk", Pillar II in the New Basel Accord - the Challenge of Economic Capital, Citeseer, pp. 179-200.

Basel Committee on Banking Supervision (2006), "International convergence of capital measurement and capital standards", Technical Report, Bank for International Settlements.

Basel Committee on Banking Supervision (2009), "Range of practices and issues in economic capital frame- works", Technical Report, Bank for International Settlements.

Basel Committee on Banking Supervision (2011), "Principles for the sound management of operational risk", Technical Report, Bank for International Settlements.

Basel Committee on Banking Supervision (2015), "Guidelines for identifying and dealing with weak banks”, Technical Report, Bank for International Settlements. 
CB Insights (2016), "The global Fintech report: 2016 in review”, available at: www.cbinsights.com/ research-fintech-2016-report (accessed 28 March 2017).

Chaffai, M. and Dietsch, M. (2015), "Modelling and measuring business risk and the resiliency of retail banks", Journal of Financial Stability, Vol. 16, pp. 173-182.

De Nederlandsche Bank (2016), "Technological innovation and the Dutch financial sector", available at: www.dnb.nl/en/binaries/Themaonderzoek\%20\%20uktcm47-336322.PDF (accessed 20 March 2017).

Deutsche Bank (2015), “Annual report 2014”, available at: https:/annualreport.deutsche-bank.com/ 2014/ar/servicepages/welcome.html (accessed 8 September 2016).

Doff, R. (2008), "Defining and measuring business risk in an economiccapital framework", Journal of Risk Finance, Vol. 9 No. 4, pp. 317-333.

Duffie, D. and Singleton, K.J. (2012), Credit Risk: Pricing, Measurement, and Management, Princeton University Press, Princeton.

European Parliament (2013), "Regulation (EU) No 575/2013”, Official Journal of the European Union.

Gorton, G. and Metrick, A. (2012), "Getting up to speed on the financial crisis: a one-weekend-reader's guide", Journal of Economic Literature, Vol. 50 No. 1, pp. 128-150.

Haddad, C. and Hornuf, L. (2016), "The emergence of the global Fintech market: economic and technological determinants", Working Paper 6131, Center for Economic Studies and the Ifo Institute, available at: https://ssrn.com/abstract=2830124

International Monetary Fund (2011), "Kingdom of The Netherlands - Netherlands: financial system stability assessment", available at: www.imf.org/external/pubs/ft/scr/2011/cr11144.pdf (accessed 31 March 2017).

KPMG (2016), "Equity market risk premium: research summary", available at: https://assets.kpmg. com/content/dam/kpmg/pdf/2016/07/MRP-Summary-July-2016.pdf (accessed 8 September 2016).

Lando, D. (2009), Credit Risk Modeling: Theory and Applications, Princeton University Press, Princeton.

McConnell, P. (2012), "The governance of strategic risks in systemically important banks", Journal of Risk Management in Financial Institutions, Vol. 5 No. 2, pp. 128-142.

McConnell, P. (2013), "Strategic risk: the beanstalk syndrome", Journal of Risk Management in Financial Institutions, Vol. 6 No. 3, pp. 229-252.

McConnell, P.J. (2016), "Strategic risk management: the failure of hbos and its regulators", Journal of Risk Management in Financial Institutions, Vol. 9 No. 2, pp. 147-162.

McKinsey (2015), "The fight for the customer: McKinsey global banking annual review 2015", available at: www.mckinsey.com/industries/financial-services/our-insights/the-fight-for-thecustomer-mckinsey-global-banking-annual-review-2015 (accessed 11 August 2016).

Mackenzie, A. (2015), “The Fintech revolution”, London Business School Review, Vol. 26 No. 3, pp. 50-53.

Noonan, L. (2016), "Growth of Fintech forecast to spur almost $2 \mathrm{~m}$ banking job cuts", Financial Times, available at: www.ft.com/content/e00f8884-f65c-11e5-96db-fc683b5e52db

Philippon, T. (2016), “The Fintech opportunity”, Working Paper 22476, National Bureau of Economic Research available at: www.nber.org/papers/w22476

PwC (2016), "Blurred lines: how FinTech is shaping financial services", available at: www.pwc.co. nz/PWC.NZ/media/pdf-documents/industries/financial-services/pwc-global-fintech-report2016-blurred-lines-how-fintech-is-shaping-financial-services.pdf (accessed 20 March 2017).

Schroeck, G. (2002), Risk Management and Value Creation in Financial Institutions, John Wiley \& Sons, Hoboken, Vol. 155.

Slywotzky, A. and Drzik, J. (2005), Countering the Biggest Risk of All, Harvard Business Review, MA.

Stulz, R.M. (2014), "Governance, risk management, and risk-taking in banks", Technical Report, National Bureau of Economic Research.

Sweeting, P. (2011), Financial Enterprise Risk Management, Cambridge University Press. 
Appendix

Strategic risk, banks and basel III

\begin{tabular}{|c|c|c|c|}
\hline Bank & Description of strategic risk in Annual report 2014 & $\begin{array}{l}\text { Economic } \\
\text { capital }\end{array}$ & \\
\hline Van Lanschot & $\begin{array}{l}\text { Strategic risk is the risk of lower income due to a change in } \\
\text { the banks environment and its activities. We define strategic } \\
\text { risk as the existing or future threat to the banks results or } \\
\text { equity resulting from failure to (fully) anticipate changes in } \\
\text { the environment and/or from incorrect strategic decisions. } \\
\text { Strategic risk arises due to changes in prices, margins and/or } \\
\text { volumes. It comprises external influences such as market } \\
\text { circumstances, reputation and regulations, and how well Van } \\
\text { Lanschots management anticipates them. Van Lanschot uses } \\
\text { the terms business and strategic risk interchangeably in the } \\
\text { annual report }\end{array}$ & e59m & 245 \\
\hline SNS & $\begin{array}{l}\text { The risk that strategic objectives are not achieved due to the } \\
\text { company's lack of response or inadequate or late response to } \\
\text { changes in the environment and the business climate }\end{array}$ & $\begin{array}{l}\text { Treated as non- } \\
\text { financial risk }\end{array}$ & \\
\hline $\operatorname{RBS}^{1}$ & $\begin{array}{l}\text { Strategic risk arises from strategic decisions that fail to } \\
\text { reflect the operating environment, or which do not take } \\
\text { adequate account of execution challenges. These include } \\
\text { decisions related to RBS products and services which have } \\
\text { implications for profitability, risk, the customer base and for } \\
\text { business growth }\end{array}$ & & $\begin{array}{r}\text { Table AI. } \\
\text { Banks that define } \\
\text { "strategic risk" }\end{array}$ \\
\hline
\end{tabular}


ABN AMRO Business risk is the risk that business earnings and franchise value decline and/ or deviate from expectations because of uncertainty in business income or in the expenses incurred to generate business income. The key criteria for classifying a risk as a business risk are: event outcome leads to uncertainty in present or future business earnings and/or franchise value and, drivers are uncertainty in volumes, margins, fee and commission rates and/or business expenses. Sensitivity to business risk drivers is mitigated by management practices that effectively and timely address developments in business risk drivers. A basic view of business risk mitigation is to address the risk that earnings will fall below the fixed cost base, due to changes in margins and volumes. The higher the variable part of the total costs, the better the ability to continue making a profit in the event of falling revenues. In addition to these management practices, business risk is mitigated by a capital buffer

ING The exposure to value loss due to fluctuations in volumes, margins and costs, as well as customer behavior risk. These fluctuations can occur because of internal, industry, or wider market factors. It is the risk inherent to strategy decisions and internal efficiency, and as such strategic risk is included in business risk

Binckbank International economic and cyclical factors and political conditions influence financial markets around the world, and consequently also affect the operating result of BinckBank. In addition, there are various factors such as loss of customers, fluctuating trading volumes and order values and price pressure due to competition, which could result in a fall in income for BinckBank. BinckBank operates in a highly competitive environment in which its competitors, often large financial institutions, have well-established brands and greater financial resources. BinckBank is also seeing further increasing competition from smaller online brokers which compete aggressively on price. BinckBank makes great efforts and substantial investments in its ICT platform and its products and services in order to attract new customers and retain existing customers. BinckBanks financial position and result can also be adversely affected by unfortunate business decisions, poor execution of business decisions or inadequate response to changes in the business climate in general or in the markets relevant to the company in particular

Deutsche Bank Business risk describes the risk we assume due to potential changes in general business conditions, such as our market environment, client behavior and technological progress, as these can affect DBs results if we fail to adjust quickly to these changing conditions. The most material aspect of business risk is "strategic risk", which represents the risk of suffering unexpected operating losses due to decreases in operating revenues which cannot be compensated by cost reductions within the respective time horizon. Strategic risk only covers revenue or cost volatility which are not attributable to position taking (market risk), credit losses (credit risk) and operational events (operational risk) Business risk is the risk that RBS suffers losses as a result of adverse variances

Table AII.

Banks that define "business risk" in its revenues, costs or both as a result of its business plan and strategy. Such variances may be caused by a variety of specific factors such as volatility in pricing, sales volumes, and input costs as well as more general factors such as exposure to macroeconomic, regulatory and industry risks

\author{
Corresponding author \\ Arun Chockalingam can be contacted at: A.Chockalingam@tue.nl
}

For instructions on how to order reprints of this article, please visit our website: www.emeraldgrouppublishing.com/licensing/reprints.htm Or contact us for further details: permissions@emeraldinsight.com 